\title{
Investigation into the bioavailability of synthesized phytosterol esters in vitro and in vivo using Caco-2 cell model and Wistar rats
}

\author{
Shirang WANG ${ }^{1,2}$, Dianyu $\mathrm{YU}^{1}$, Yongge $\mathrm{SHI}^{3}$, Lianzhou JIANG ${ }^{1}$, Fuming $\mathrm{YANG}^{1 *}$ (D), Guoping YU ${ }^{1 *}$
}

\begin{abstract}
Phytosterols are bioactive components capable of reducing the level of cholesterol in serum. In this study, phytosterol acetic ester (PA), phytosterol oleate ester (PO) and phytosterol linoleic ester (PL) were synthesized from phytosterol (PS) and organic acid to improve the solubility of phytosterols in oil. The purities of PA, PO and PL were 98.4, 95.9 and 95.7\%, respectively. Caco-2 cell monolayers and Wistar rats were used to research the bioavailability of synthesized esters (PE) in vitro and in vivo. Experiments using the Caco-2 cell monolayer model showed that the transport mechanism of phytosterol esters was passive transport. Experiments in vivo showed that the PS content in rat blood reached the highest level at $3 \mathrm{~h}$, with a value of $21.82 \mu \mathrm{g} / \mathrm{mL}$. PS content in the liver was the highest at $3 \mathrm{~h}$, with a value of $43.65 \mu \mathrm{g} / \mathrm{g}$. Bioavailability of PL is the highest, reaching a value as high as $19.57 \%$. Acute study in the rats showed that the PS concentration in blood was at the safe level, and it had no side effects for health. In conclusion, the bioavailability of PL and PO is better than PS, PL and PO have more advantages in application.
\end{abstract}

Keywords: phytosterol esters; cell model; in vivo absorption; bioavailability.

Practical Application: Phytosterol acetic ester, phytosterol oleate ester and phytosterol linoleic ester were synthesized from phytosterol and organic acid, the bioavailability of phytosterol linoleic ester and phytosterol oleate ester is improved significantly than phytosterol. Phytosterol linoleic ester and phytosterol oleate ester have more potential applications in the nutraceuticals and prospective nutrient supplements.

\section{Introduction}

Phytosterols are natural components of the diet found in vegetable products, such as vegetable oils, nuts and grains (Bacchetti et al., 2011; Fakih et al., 2018). Studies have shown that phytosterols can reduce cholesterol levels in the serum (Belo et al., 2018; Rocha et al., 2011), reduce the risk of human colon cancer (Bradford \& Awad, 2007; Huang, et al., 2017) and have potential nutritional effects on gastrointestinal inflammatory diseases. However, the content of phytosterols in natural food is low, and phytosterols are insoluble in water. The solubility of phytosterols in edible oil is only $1 \%$. It is difficult to meet the supplementary recommendation of $2 \mathrm{~g}$ for adults, which limits its application greatly (Gylling et al., 2014). To overcome these problems, phytosterol acetic ester (PA), phytosterol oleate ester (PO) and phytosterol linoleic ester (PL), as well as other phytosterol esters, were synthesized from phytosterol (PS) and organic acid for improving the total amount in food and oil solubility of phytosterol (Hellner et al., 2010). After esterification, the solubility of phytosterols in oil was greatly improved. Phytosterol esters (PE) can be transformed into phytosterols and fatty acids after digestion in the human body, and their biological activities remain unchanged. Phytosterol esters are emulsified by bile and hydrolyzed by lipase after entering into the human body. Then, phytosterol esters enter into the blood circulation and reach tissues through intestinal absorption. They are digested and utilized by the human body to exert their biological effects (Nestel et al., 2001; Moghadasian et al., 2016).

PE are mainly synthesized through chemical-catalyzed esterification and biological-catalyzed esterification. Chemical synthesis has several advantages including good conversion rate and high productivity. However, it has several drawbacks too. For example, chemical esterification requires the use of catalysts such as magnesium oxide, lanthanum oxide, zinc oxide, aluminum oxide, and aluminum triiodide (Hang \& Dussault, 2010; Meng et al., 2011; Valange et al., 2008). The major challenge is the difficulty in separating catalyst from the final product. Another major challenge is the high temperature used during the synthesis, which may lead to the production of by-product. Lipase-catalyzed reactions provide a potential alternative for producing $\mathrm{PE}$ because these reactions can be performed under mild conditions and produces no or less by-product. However, biological synthesis takes a longer time with low conversion rate products and its cost is very high (Villeneuve et al., 2005). There is an urgent need for green synthesis technology to obtain high-quality phytosterol ester products.

In recent years, the use of noncatalytic reactions has been recognized as an ecofriendly method for esterification (He et al., 2014; Prasanna Rani et al., 2016). In this process, the use of noncatalytic 
reactions eliminates the problems associated with both chemical and enzyme-catalyzed methods and ensures the quality of the phytosterol ester product. Nguyen et al. (2019) successfully obtained PE using microwave irradiation for the noncatalytic esterification of PS with oleic acid. In their report, the PS conversion of $95.42 \%$ was achieved at a temperature of $180^{\circ} \mathrm{C}$, microwave power of $200 \mathrm{~W}$, oleic acid:phytosterols molar ratio of 5:1, and reaction time of $50 \mathrm{~min}$. This method required a high temperature $\left(180^{\circ} \mathrm{C}\right)$ and high molar ratio. Recently, we also tried the method of noncatalytic reactions. We synthesized PE using PS from soybean and acetic anhydride (Yang et al., 2016). The optimum condition for the production of high conversion rate $(99.4 \%)$ was found to be a temperature of $135^{\circ} \mathrm{C}$ for $1.5 \mathrm{~h}$ with a molar ratio $1: 1$ for PS and acetic anhydride, respectively. Furthermore, PL was synthesized from soybean sterol and linoleic acid using acyl chloride method. Under the optimized condition of 1:1.1 molar ratio of PS and linoleoyl chloride at $80^{\circ} \mathrm{C}$ for $1.5 \mathrm{~h}$, the conversion rate of PS reached 96.1\% (Yang et al., 2018b). The method we tried is milder than previous studies. In this paper, PA was synthesized from soybean and acetic anhydride using the same method as before, PO and PL were synthesized using acyl chloride method.

PS and PE are generally recognized as safe, a series of safety evaluation have been reported for the assessment of mutagenic activity, oestrogenicity, genotoxicity and subchronic toxicity (Baker et al., 1999; Wolfreys \& Hepburn, 2002; Lea et al., 2004). No obvious side effects of PS and PE have been observed in studies of Wistar derived rats with a dose of $6.6 \mathrm{~g} / \mathrm{kg}$ body weight $/$ day PE or $4.1 \mathrm{~g} / \mathrm{kg} /$ day PS (Hepburn et al., 1999). It has been proposed that inadequate esterification of PS may play a role in the poor intestinal absorption of PS. It is important to increase phytosterol absorption and bioavailability in the body (Moreau et al., 2018). Plasma levels of PS have been showed to increase up to two-fold by dietary intakes of $160-360 \mathrm{mg} /$ day PS than normal dietary conditions. The plasma levels of PS supplementation is a safe concentration for human body except in individual with sitosterolemia. Sitosterolemia is a rare inherited lipid storage disease, and the absorption rate of PS is very high in the patients, plasma concentrations of PS are approximately 50-100 times higher than that in normal populations (Kritchevsky \& Chen, 2005). Large amounts of PS deposition in tissues is toxic for health, particularly in certain populations with genetic defect (Ling \& Jones, 1995). In normal populations, the PS absorption is very poor, and the amounts of PS intakes is inadequate (Marangoni \& Poli, 2010). Thus, the proper increase of PS absorption and bioavailability in the body is important, and has no side effects on healthy subjects.

Caco- 2 cells are derived from human colon adenocarcinoma and morphologically resemble enterocytes of the small intestine (Daujat et al., 1996; Vila et al., 2018). The cells formulated monolayers that have intercellular tight junctions and microvilli and exhibit brush-border characteristics at the apical side. They were used for several years to primarily assess cell absorption and transportation (Trujillo et al., 2016; Keemink \& Bergström, 2018). In recent decades, Caco-2 cell monolayers have been widely used as a standard in vitro assay to analyze the absorption and transport mechanisms of drugs and nutrients (Ghietto et al., 2017; Elendran et al., 2019). Animal experiments are effective means to simulate human digestion and absorption. For further exploration of absorption, distribution and excretion of phytosterols and sterol esters in the body, rats can be used as experimental animals to analyze the bioavailability of phytosterols in blood, organs, feces and urine.

Bioavailability refers to the proportion of nutrients entering into the blood circulation or reaching tissues after digestion and absorption in the body (Fernández-García et al., 2009). Whether or not the absorbance rate of these synthetic phytosterol esters exceed those of natural phytosterols, their bioavailability needs to be evaluated. The gastrointestinal absorption mechanism of these synthetic sterol esters deserves further study, and it is of great significance for their further application (Ito et al., 2012). In this study, to explore potential applications in the clinic or nutraceuticals and make them prospective nutrient supplements, the bioavailability of synthesized phytosterol esters will be assessed initially through their absorption and transport characteristics in the Caco-2 cell line, and then their absorption and tissue distribution will be tested directly in rats. It is an acute study in the rats, the PS concentration in blood was studied up to 5 hours and the tissue analysis were at 3 hours.

\section{Materials and methods}

\subsection{Materials}

Phytosterols (from soybean, $\geq 99 \%$ ) were purchased from Jiusan Grains \& Oils Industries Group Co., Ltd. (China). Standards of campesterol ( $\geq 98 \%)$, stigmasterol $(\geq 98 \%)$, and $\beta$-sitosterol $(\geq 98 \%)$ were purchased from Chengdu Purification Technology Development Co., Ltd. (China). Linoleic acid $(\geq 99 \%)$, oleic acid $(\geq 99 \%)$, DMEM high sugar culture medium, serum culture medium, propranolol hydrochloride, alkaline phosphatase (ALP) kit, and 12-well polyester membrane plates (Transwell) were purchased from Sigma-Aldrich Company (America).

PA, PO and PL were prepared in our laboratory (their chemical structures were as shown in Figure 1) (Yang et al., 2016, 2018b). The Caco-2 cell line was from the College of Life Sciences and Engineering in Northeast Forestry University (China). Male Wistar rats were purchased from the Animal Laboratory Center of Harbin Medical University (China). Each rat weighed between 230 and $270 \mathrm{~g}$ ( 6 weeks old) and was housed separately in metabolism cage, with 1 rat per cage. The animals were fed standard pellet, virtually phytosterol free, and allowed access to bottled drinking water.

\subsection{HPLC analysis}

Components of phytosterol and phytosterol esters were analyzed using HPLC (2695-UV2489, Waters, USA), which was performed on a $\mathrm{C} 18(4.6 \mathrm{~mm} \times 250 \mathrm{~mm}, 5 \mu \mathrm{m})$ reversephase column maintained at $30^{\circ} \mathrm{C}$. The mobile phase was acetonitrile and acetone $(1: 3, \mathrm{v} / \mathrm{v})$ with a $1.0 \mathrm{~mL} / \mathrm{min}$ flow rate. The absorbance detector wavelength was set at $210 \mathrm{~nm}$, and the injection volume was $20 \mu \mathrm{L}$ (Yang et al., 2016).

\subsection{Caco-2 cell monolayer model}

\section{Culture of the Caco-2 cell monolayer}

Caco- 2 cell line was from Northeast Forestry University, 2937 passage cells were used in the experiments. The cryopreserved 
<smiles>[R]C1CCC2C3CC=C4CC(O)CCC4(C)C3CCC12C</smiles>

A<smiles>[R]C1CCC2C3CC=C4CC(OC(C)=O)CCC4(C)C3CCC12C</smiles>

$\mathrm{C}$<smiles>[R]C1CCC2C3CC=C4CC(OC(C)=O)CCC4(C)C3CCC12C</smiles>

B<smiles>[R]C1CCC2C3CC=C4CC(OC(C)=O)CCC4(C)C3CCC12C</smiles>

D

(A) phytosterol, (B) phytosterol acetic ester, (C) phytosterol linoleic ester, (D) phytosterol oleate

ester; $\mathrm{R}$ represents the chemical structure of

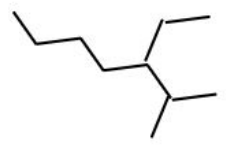
$(\beta$-sitosterol),

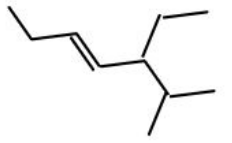

(stigmasterol),<smiles>CCCCCCCCCCC#CC(C)C(C)CCCC</smiles>

Figure 1. Chemical structure of phytosterol and phytosterol esters.

Caco- 2 cell line was thawed rapidly in a water bath $\left(37^{\circ} \mathrm{C}\right)$, and then centrifuged at $5000 \mathrm{rpm}$ for $5 \mathrm{~min}$. The cryopreservation solution was discarded and the Caco- 2 cells were transferred to $25 \mathrm{~mL}$ of DMEM high glucose medium (10\% FBS, $1 \%$ nonessential amino acids, $1 \%$ glutamine, $100 \mathrm{U} / \mathrm{mL}$ penicillin and $100 \mathrm{U} / \mathrm{mL}$ streptomycin were added in the DMEM). The medium was changed every other day in the incubator with $\mathrm{CO} 2$ concentration of $5 \%$, relative humidity of $90 \%$ and temperature of $37^{\circ} \mathrm{C}$. When the cells reached about $80 \%$ fusion (Caco- 2 cells covered the bottle wall), the medium was discarded, Caco- 2 cells were washed with $1 \mathrm{~mL}$ PBS solution. $2 \mathrm{~mL}$ solution of $0.25 \%$ trypsin-EDTA was added for 3-5 min, then $5 \mathrm{~mL}$ DMEM medium was added. Finally, Caco-2 cells were mixed with a pipette, and the cells were used for culture and passage.

Caco-2 cells were inoculated onto 12 -well transwell plates at a density of $1.0 \times 10^{5} / \mathrm{cm}^{2}$. DMEM $(0.5$ and $1.5 \mathrm{~mL})$ was added to the apical side (AP side) and the basolateral side (BL side) of the transwell polycarbonate membrane, respectively (Figure 2). The medium in both the AP and BL sides was changed every 2 days for the first week and every day until reaching 21 days (Zeng et al., 2017) . Integrity and permeability are two important indexes of the Caco-2 cell model, and activity of alkaline phosphatase and permeability of the apparent coefficient were detected.

\section{Integrity of the Caco-2 cell monolayer}

The activity of alkaline phosphatase in Caco-2 cells was detected at 5, 15 and 21 days by an alkaline phosphatase detection kit to ensure the cell model was established successfully (Wahlang et al., 2011). The specific experiment was carried out according to the instructions of the alkaline phosphatase (ALP) kit and referring to other researchers (Turowski et al., 1994).

Alkaline phosphatase (ALP) is a brush-like edge enzyme that differentiates during the formation of the Caco-2 cell monolayer; it reflects the degree of cell differentiation and functional status. ALP activity on both the AP and BL sides was measured to confirm the integrity of the Caco- 2 cells. It takes 21 days to establish a model of the Caco- 2 cell monolayer. Therefore, ALP activity was measured on days 5,15 and 21 of cell culture (Table 1).

The results showed that ALP activity of the AP and BL sides increased significantly over time and that the ALP activity of 


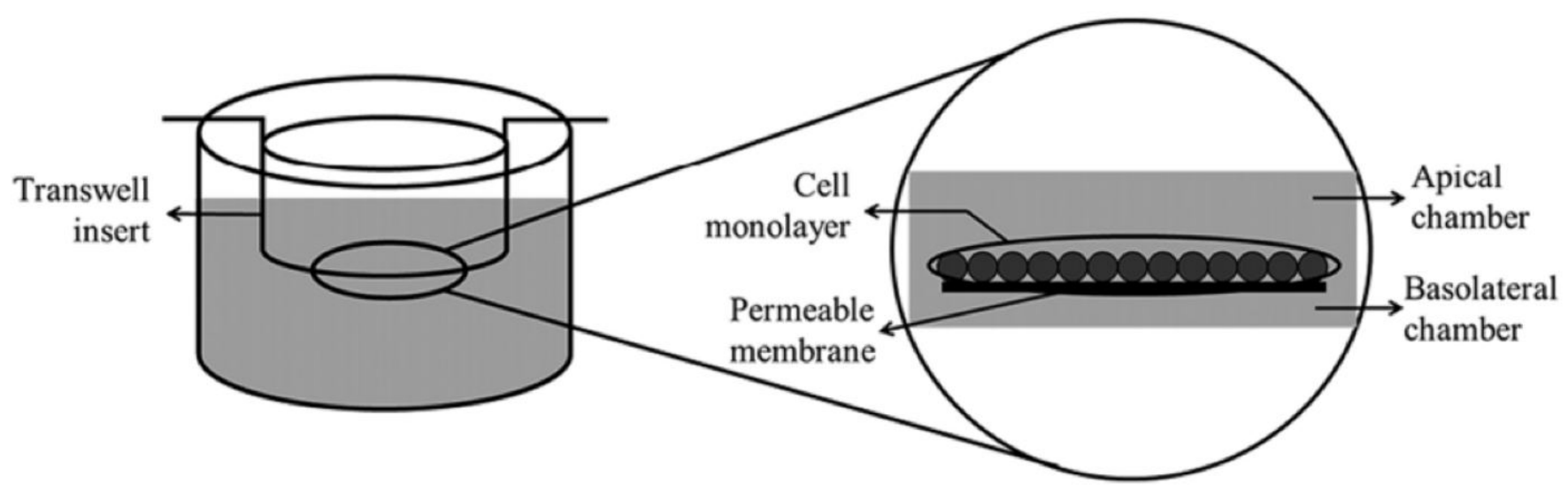

Figure 2. Culture of Caco-2 cell monolayer.

Table 1. Alkaline phosphatase activity of Caco-2 cell monolayer at different time (U/L).

\begin{tabular}{cccc}
\hline \multirow{2}{*}{ Time $(\mathrm{d})$} & \multicolumn{3}{c}{ Activity of alkaline phosphatase } \\
\cline { 2 - 4 } & Apical side & Basolateral side & AP/BL \\
\hline 0 & 0 & 0 & ---- \\
5 & $16.2^{\mathrm{c}} \pm 0.22$ & $11.8^{\mathrm{c}} \pm 0.18$ & 1.37 \\
15 & $40.5^{\mathrm{b}} \pm 0.32$ & $13.9^{\mathrm{b}} \pm 0.21$ & 2.91 \\
21 & $68.1^{\mathrm{a}} \pm 0.78$ & $15.3^{\mathrm{a}} \pm 0.23$ & 4.45 \\
\hline
\end{tabular}

Mean \pm SD. Mean with different superscript along the same column are significantly different $(\mathrm{p}<0.05)$.

the AP side increased faster. From days 5 to 21 , the ALP on the AP side increased 4 times (from 16.2 to $68.1 \mathrm{U} / \mathrm{L}$ ), but the ALP activity on the BL side only increased slightly to $15.3 \mathrm{U} / \mathrm{L}$. The ratio of $\mathrm{AP} / \mathrm{BL}$ at each time point showed the same trend, increasing up to 4.45 times. This finding indicates that ALP activity was mainly concentrated on the side of the AP brush edge, and the distribution of the AP and BL sides was asymmetric. The Caco-2 cell monolayer formed was compact and complete enough to be suitable for further absorption and transport experiments (Yang et al., 2018a).

\section{Permeability of the Caco-2 cell monolayer}

Propranolol hydrochloride (a high bioavailable drug) is used as a marker of transcellular transport in the Caco-2 cell monolayer model (Yang et al., 2007). The transport of propranolol hydrochloride from the AP to the BL side of the Caco-2 cell model was studied at $\mathrm{pH}$ 7.2-7.4. Before the experiment, cell layers established for 21 days were washed with phosphate buffered saline (PBS) three times to remove impurities on the surface of the Caco-2 monolayer cells. Caco- 2 cells were incubated for $30 \mathrm{~min}$ in a $\mathrm{CO}_{2}$ incubator at $37^{\circ} \mathrm{C}$. The PBS solution in the pores was removed. Subsequently, $0.5 \mathrm{~mL}$ of $40,60,80$, and $100 \mu \mathrm{g} / \mathrm{mL}$ of propranolol hydrochloride was added to the AP side, and $1.5 \mathrm{~mL}$ of blank PBS was added to the BL side; finally, the transwell plate was placed in an incubator at $37^{\circ} \mathrm{C}$ for $2 \mathrm{~h}$. The solution of BL side was collected; the concentration of propranolol hydrochloride was determined by HPLC, and the permeability of apparent coefficient (Papp, $\mathrm{cm} / \mathrm{s}$ ) was calculated according to Formula 1.

Papp $=(d Q / d t) / A C_{0}$

where $d Q$ is the drug delivery quantity in $\mu \mathrm{g}, d t$ is the unit time in seconds, $A$ is area of the transported membrane $\left(1.12 \mathrm{~cm}^{2}\right)$, and $C_{0}$ is the initial concentration of propranolol $(100 \mu \mathrm{g} / \mathrm{mL})$.

The Papp of the propranolol hydrochloride solution at different concentrations from the AP to the $\mathrm{BL}$ side is higher than $1.57 \times 10^{-5} \mathrm{~cm} / \mathrm{s}$ with an average value of $1.66 \times 10^{-5} \mathrm{~cm} / \mathrm{s}$ (Table 2). In general, compounds with Papp $<1 \times 10^{-6}$, $1 \times 10^{-6}-10 \times 10^{-6}$, and $>10 \times 10^{-6} \mathrm{~cm} / \mathrm{s}$ will be poorly $(0 \sim 20 \%)$, moderately (20 70\%) and well (70 100\%) absorbed (Yee, 1997; Artursson et al., 2012). The Papp (average $1.66 \times 10^{-5} \mathrm{~cm} / \mathrm{s}$ ) of propranolol hydrochloride in the Caco- 2 cell model is higher than the standard value of well absorbed, which indicates that the propranolol hydrochloride permeability of the Caco- 2 cell monolayer is good and that this model can meet the requirement of absorption and transport experiments.

\subsection{Absorption of phytosterol esters in Caco-2 cells}

PS and PA were powders, they were dissolved in ethanol and then dispersed in sodium carboxymethyl cellulose (CMC-Na) aqueous solution. PO and PL were oils, they were prepared in stable aqueous solution with a small amount of Tween 80 emulsification.

The Caco- 2 cell suspension was inoculated in a $60 \mathrm{~mm}$ culture dish at a density of $2 \times 10^{4} / \mathrm{mL}$. After culture for 6-8 days, the cells fused in the culture dish. The medium was replaced with $5 \mathrm{~mL}$ of PBS, and the cells were incubated for $15 \mathrm{~min}$ in a $37{ }^{\circ} \mathrm{C}$ incubator. Then, the cells were cultured with $10 \mathrm{~mL}$ of medium containing PS $(120 \mu \mathrm{g} / \mathrm{mL})$, PA $(160 \mu \mathrm{g} / \mathrm{mL})$, PO $(200 \mu \mathrm{g} / \mathrm{mL})$, or PL $(200 \mu \mathrm{g} / \mathrm{mL})$ and incubated for $0.5,1,2,4$, 6 , and $8 \mathrm{~h}$. The chemical structures of PS, PA, PO and PL were different (Figure 1), phytosterol esters could be transformed into phytosterols and fatty acids after digestion in the human body. Therefore, mass of PA, PO and PL was converted to the mass of PS, the concentrations of PS, PA, PO and PL were different. The cells were washed 3 times with PBS; then, $2 \mathrm{~mL}$ of the lysate 
Table 2. The apparent permeability coefficient of Caco-2 cell monolayer at different propranolol hydrochloride concentrations.

\begin{tabular}{cc}
\hline propranolol hydrochloride $(\mu \mathrm{g} / \mathrm{mL})$ & $\mathrm{P}_{\text {app }}\left(\times 10^{-5} \mathrm{~cm} / \mathrm{s}\right)$ \\
\hline 40 & $1.73 \pm 0.19$ \\
60 & $1.71 \pm 0.22$ \\
80 & $1.64 \pm 0.15$ \\
100 & $1.57 \pm 0.21$ \\
\hline
\end{tabular}

(10\% Triton-ethanol solution) buffer was added, and the cells were scraped into a Petri dish and then transferred to a $2 \mathrm{~mL}$ centrifuge tube. The tube was vortexed thoroughly, and the cells were sonicated for $2 \mathrm{~min}$ and centrifuged at $5,000 \mathrm{rpm}$ for $5 \mathrm{~min}$. After the supernatant was absorbed and dried with nitrogen, PS, $\mathrm{PA}, \mathrm{PO}$, and PL were redissolved in acetone to $1 \mathrm{~mL}$. The contents of PS, PA, PO, and PL were determined by HPLC.

\subsection{Phytosterol and phytosterol ester transport in Caco-2 cells}

The transport of phytosterol and phytosterol esters in Caco-2 cells was recorded according to methods of Zeng et al. (2017) and Li et al. (2017) with some modifications.

First, $0.5 \mathrm{~mL}$ of prewarmed $\left(37^{\circ} \mathrm{C}\right)$ PBS buffer was added to the transwell chamber of the Caco- 2 cells. The transwell plate was equilibrated for $15 \mathrm{~min}$ in the cell culture incubator and then rinsed slightly to remove cell surface attachments. PBS solution containing $100 \mu \mathrm{g} / \mathrm{mL}$ phytosterol or phytosterol ester was added to the AP side, blank PBS solution was added to the BL side, and the plate was shaken in a constant temperature air-bath oscillator at $37^{\circ} \mathrm{C}$ at $50 \mathrm{rpm}$. Then, $500 \mu \mathrm{L}$ aliquots of the samples were taken from the BL side at 1, 1.5, 2, 2.5 and $3 \mathrm{~h}$, and an equal volume of blank PBS solution was added to the $\mathrm{BL}$ side to measure the transport amount from the AP to the $\mathrm{BL}$ side. The transport amount from the $\mathrm{BL}$ to the $\mathrm{AP}$ side was also measured, and the effects of PS, PA, PO and PL on cell transport were investigated.

\subsection{Animal studies}

Seventy-eight rats were randomly divided into 13 groups (6 rats per group) consisting of one blank group and three different doses (high, middle and low) of PS, PA, PO and PL according to Ren (Ren et al., 2016). The high, middle and low concentrations $(\mathrm{mg} / \mathrm{mL})$ of PS $(80,40$, and 4$)$, PA $(88,44$, and 4.4), PO (130, 65, and 6.5) and PL $(130,65$, and 6.5) were prepared in a CMC-Na suspension. Other 78 rats were divided into the same 13 groups, and they were kept in metabolic cages to collect urine and feces within 24 hours. The low concentrations were chosen according to the recommendation of $2 \mathrm{~g}$ for adults, the middle and high concentrations were 10 times and 20 times higher than the low concentrations. Mass of PA, PO and PL was also converted to the mass of PS, the body weight of adults was caculated as $62.5 \mathrm{~kg}$.

\section{Phytosterol concentration in blood}

Rats that were fasted for $12 \mathrm{~h}$ were given either a test sample ( 1 mL/125 g body weight) or saline, for the control group, through oral gavage. Rats in blank group did not receive intragastric administration. Then, $0.3 \mathrm{~mL}$ of venous blood was drawn from the eye vein at time points $1,2,3,4$, and $5 \mathrm{~h}$ after oral gavage administration and kept in a heparinized tube. The tubes were centrifuged at $3000 \mathrm{rpm} / \mathrm{min}$ for $15 \mathrm{~min}$, and plasma was collected and analyzed by HPLC.

\section{Distribution of phytosterol in rat organs}

The digestion time of foods in animal body is different. It is generally considered that it takes $2-4$ hours for lipids to digest in the body (Ye et al., 2019; Mu \& Porsgaard, 2005). Therefore, $3 \mathrm{~h}$ was chosen as the digestion time in this experiment. After $3 \mathrm{~h}$ of intragastric administration, the rats were sacrificed, and their heart, liver, spleen, lung, and kidney tissues were obtained. Blood on the tissue surface was rinsed off, and the tissues were homogenized in $20 \mathrm{~mL}$ of saline. Then, $10 \mathrm{~mL}$ of $\mathrm{N}$-hexane was added to the solution. The supernatant was collected after mixing with whirlpool oscillation and extracted repeatedly three times. The supernatant was pooled and dried in nitrogen. The residue was dissolved in $1 \mathrm{~mL}$ of ethanol for further HPLC analysis to detect the distribution of phytosterols in rat organs.

\section{Phytosterol content in rat excreta}

After intragastric administration, the urine from the entire $24 \mathrm{~h}$ period was collected into a $50 \mathrm{~mL}$ tube, the feces from the entire $24 \mathrm{~h}$ period were collected into another $50 \mathrm{~mL}$ tube. $10 \mathrm{~mL}$ of $\mathrm{n}$-hexane was added into the $50 \mathrm{~mL}$ tube, sonicated for $15 \mathrm{~min}$, and extracted repeatedly three times. The supernatant was dried and redissolved in $1 \mathrm{~mL}$ of acetone, and the acetone extract was filtered with a $0.45 \mu \mathrm{m}$ membrane and then analyzed for the contents of PS, PA, PO, and PL by HPLC.

Excretion proportion was calculated according to the following Formula 2:

$E_{P}=\left(P_{F} / P_{G}\right) \times 100 \%$

where $E_{\mathrm{p}}$ is excretion proportion (\%), $P_{\mathrm{F}}$ is the quality of sterols in urine or feces $(\mathrm{mg})$, and $P_{\mathrm{G}}$ is the total mass of sterols by intragastric administration (mg).

Bioavailability was calculated according to the following Formula 3:

$B_{V}=\left(1-P_{F} / P_{G}\right) \times 100 \%$

where $B_{\mathrm{V}}$ is bioavailability (\%), $P_{\mathrm{F}}$ is the quality of sterols in urine or feces $(\mathrm{mg})$, and $P_{\mathrm{G}}$ is the total mass of sterols by intragastric administration (mg).

\subsection{Statistical analysis}

All of the experiments were did three times, and the results are expressed as the mean \pm SD. Statistical analysis was performed by analysis of variance (ANOVA) then by Tukey's post-hoc for multiple comparisons $(\mathrm{p}<0.05)$ using the Statistical Package for the Social Sciences v. 20.0 (SPSS, Chicago, IL, USA). 


\section{Results and discussion}

\subsection{Composition of phytosterol esters}

The purities of PA, PO and PL were 98.4, 95.9 and 95.7\%, respectively, as determined by HPLC (Figure 3 ). The product purity was sufficient to meet the requirement in food, medicine, nutraceuticals and cosmetic applications (Yang et al., 2016, 2018b). The components of PA, PO and PL were also analyzed by HPLC. Retention time of campesterol acetic ester, stigmasterol

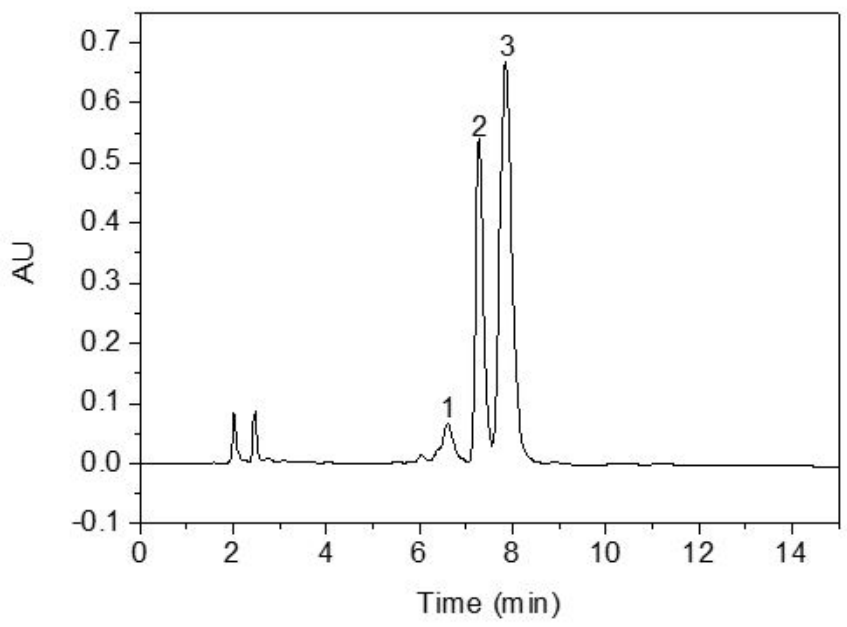

A

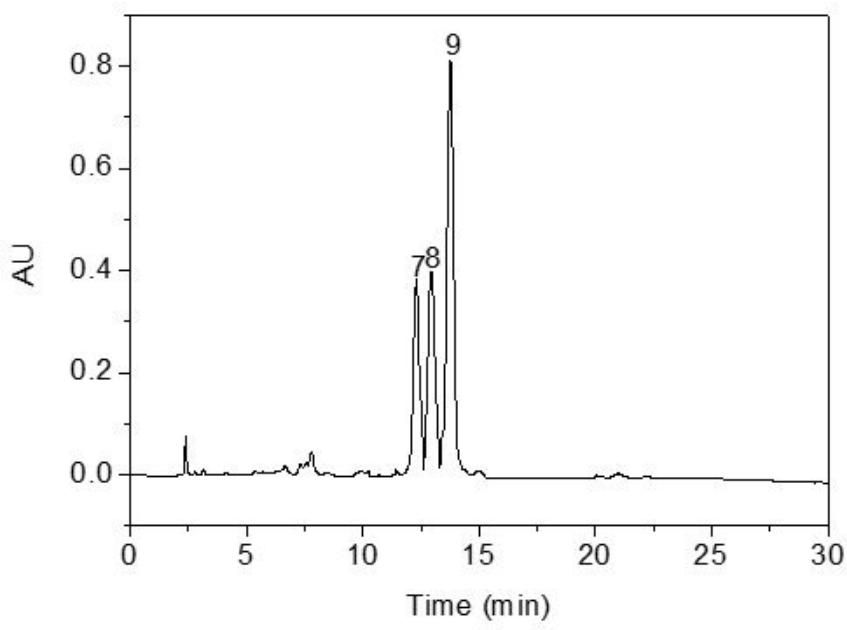

C acetic ester, $\beta$-sitosterol acetic ester, campesterol linoleic ester, stigmasterol linoleic ester, $\beta$-sitosterol linoleic ester, campesterol oleate ester, stigmasterol oleate ester and $\beta$-sitosterol oleate ester were 8.8, 9.6, 10.1, 12.3, 13.0, 13.7, 19.8, 20.6 and $21.9 \mathrm{~min}$ respectively, which corresponds to the chromatograms in Figure 3B, Figure 3C and Figure 3D. Although the product may have residual PS and acetic acid, linoleic acid, oleic acid, the quantities of these components are negligible amount and may not be detrimental to both product quality and human health (Yang et al., 2016, 2018b).

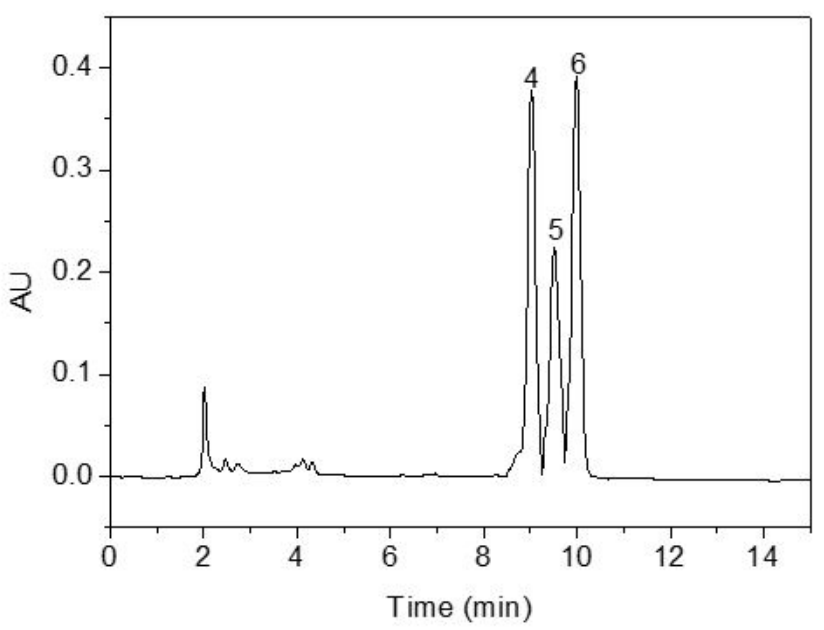

B

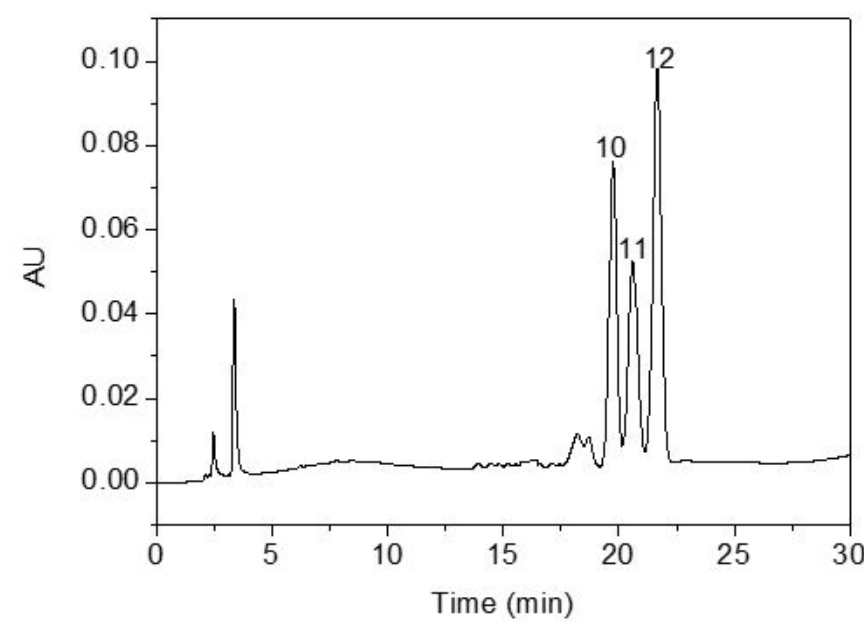

D

Figure 3. HPLC chromatograms of phytosterol and phytosterol esters. (A) phytosterol; (B) phytosterol acetic ester; (C) phytosterol linoleic ester; (D) phytosterol oleate ester. (1) campesterol; (2) stigmasterol; (3) $\beta$-sitosterol; (4) campesterol acetic ester; (5) stigmasterol acetic ester; (6) $\beta$-sitosterol acetic ester; (7) campesterol linoleic ester; (8) stigmasterol linoleic ester; (9) $\beta$-sitosterol linoleic ester; (10) campesterol oleate ester; (11) stigmasterol oleate ester; (12) $\beta$-sitosterol oleate ester. 


\subsection{Bioavailability of phytosterol esters in vitro}

\section{Absorption of phytosterol esters in Caco-2 cells}

The absorption of phytosterol and phytosterol esters gradually increased over time and reached a plateau after 4 or $6 \mathrm{~h}$ (Figure 4). The absorption of PL and PO in Caco-2 cells was the highest, reaching $78.89 \pm 2.82$ and $75.93 \pm 2.64 \mu \mathrm{g} / \mathrm{g}$, respectively, after culture for $4 \mathrm{~h}$. Absorption values of PL and PO did not change significantly $(\mathrm{p} \geq 0.05)$ at $6 \mathrm{~h}$ and $8 \mathrm{~h}$. Both PA and PS absorption levels in Caco-2 cells were lower than those for PL and PO, reaching $25.84 \pm 0.86$ and $14.84 \pm 0.56 \mu \mathrm{g} / \mathrm{g}$, respectively, at $6 \mathrm{~h}$. Then, the absorption of PA and PS reached stable state after culture for $6 \mathrm{~h}$. This showed that the absorption of phytosterols and phytosterol esters in Caco-2 cells increased gradually over time and reached equilibrium after 4 or $6 \mathrm{~h}$; the absorption values from high to low are PL, PO, PA, and then PS. These differences may due to their different fat solubilities (Nestel et al., 2001). Higher solubility of lipids results in greater ease of the molecules entering into the lipids of cell membranes. PS and PA are insoluble in water and poorly soluble in oil, which are dispersed in CMC-Na aqueous solution in the form of particulates through ethanol dissolution. PO and PL have good solubility in oil, and they are dispersed in aqueous solution in the form of microdroplets through emulsifier Tween 80 emulsification. Small droplets can go through cell membranes by direct diffusion. A slightly larger particle enters into the cell in the form of endocytosis, and the transmembrane transport efficiency is slightly lower (Gol et al., 2018).

\section{Transport of phytosterol esters in Caco-2 cells}

Studies on transport of Caco- 2 cell model in vitro can provide evidence for understanding of absorption and transformation of PS and PE in the intestine (Xiang et al., 2020). Transport of phytosterol and phytosterol esters from the AP to BL side of Caco-2 cells increased gradually from 1 to $3 \mathrm{~h}$ (Figure $5 \mathrm{~A}$ ). The transmembrane transport of phytosterol and phytosterol esters was positively

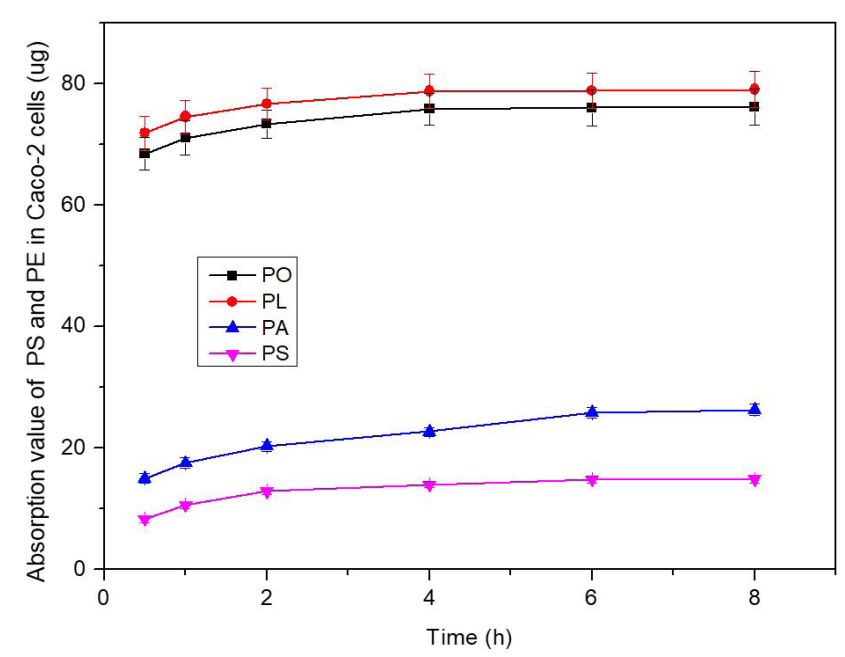

Figure 4. Effect of time on cell absorption of phytosterol and phytosterol esters in Caco-2 cell monolayer. correlated with time. The cumulative transport amounts of PS, PA, PO and PL were $8.58 \pm 0.51,13.08 \pm 0.82,24.65 \pm 0.78$ and $27.26 \pm 0.76 \mu \mathrm{g}$ for $3 \mathrm{~h}$, respectively. Transport values increased linearly with time (Figure 5A). There are generally four routes for nutrient transport in Caco-2 cells: passive diffusion, paracellular transport, transcytosis and endocytosis (Iftikhar et al., 2020). Passive diffusion is a kind of transport mode in which substances are transported along the concentration gradient without consuming adenosine triphosphate (ATP). The transport power comes from the concentration gradient potential energy of substances inside and outside the plasma membrane. The transport of phytosterol and phytosterol esters in the Caco- 2 cell monolayer occurred from high to low concentration, potentially due to a passive diffusion mechanism (Yang et al., 2007). In this process, transport across a cell membrane depends on the concentration gradient of the solute (along the concentration gradient). This mechanism was similar with previous studies of olive oil hydroxytyrosol, the kinetic data demonstrated that hydroxytyrosol transport occurred via a passive diffusion mechanism (Manna et al., 2000). Another mechanism study of retinol transport found that retinol were also transported through Caco-2 cells by passive diffusion (During \& Harrison, 2007). Their report is in agreement with our results.

Similar to the results of transport from the AP to $\mathrm{BL}$ side, the transport of phytosterol and phytosterol esters from the BL to AP side increased gradually over time (Figure 5B). The transmembrane transport of phytosterol and phytosterol esters was positively correlated with incubation time. The cumulative transport amounts of PS, PA, PO and PL from the BL to AP side were $12.44 \pm 0.53,21.06 \pm 0.81,50.30 \pm 0.79$ and $58.08 \pm 1.16 \mu \mathrm{g}$, respectively. Transport from the BL to AP side was higher than that from the AP to BL side (Figure 5B). This result suggests that, in addition to passive diffusion, there may be an active transport mechanism occurring for phytosterol and phytosterol esters in the Caco- 2 cell monolayer (inverse the concentration gradient).

\subsection{Bioavailability of phytosterol esters in vivo}

\section{Phytosterol concentration in rat blood}

Absorption of PL and PO reached a peak at $3 \mathrm{~h}$, the absorption of PA and PS reached a peak at $4 \mathrm{~h}$, and the order of absorption was PL $>$ PO $>$ PA $>$ PS (Table 3). From analysis of the phytosterol concentration in blood, the bioavailabilities of PO and PL were significantly higher than those of PA and PS (Table 3). There was no significant difference $(p \geq 0.05)$ in blood concentration between the PS and PA groups, which showed that the bioavailabilities of PS and PA were similar and that PA did not improve the PS bioavailability. This result may be related to the lipophilicity, state and structure of phytosterol esters. PL and PO have high fat solubility, and they are liquid at body temperature $\left(37^{\circ} \mathrm{C}\right)$; thus, their bioavailability is high (Nestel et al., 2001). The structures of PA and PS are similar. PA and PS are powder at body temperature, and their solubilities in oil are not very good; thus, their bioavailabilities are lower than those of PL and PO, which is quite consistent with the in vitro results.

Phytosterol could be detected in rat blood of high and middle dose phytosterol and phytosterol ester groups, and no 
phytosterol were detected in the rat blood of low dose and blank group (there were no data of low dose and blank group shown in Table 3). This finding may be attributed to phytosterol ester being hydrolyzed into phytosterol and fatty acid in the rat's body, and phytosterol ester may perform its biological role through phytosterol in the body (Nestel et al., 2001). The absorption of phytosterol esters in vivo may be similar to that of fats. Fats are first emulsified into emulsions by bile and then hydrolyzed into sterols and fatty acids by lipase, phospholipase and cholesterol esterase (Nestel et al., 2001; Delaney et al., 2004). Phytosterol and phytosterol ester were not detected in the blood of rats in the low dose group (Table 3). This lack of detection was due to the low bioavailability of phytosterol and phytosterol ester. The absorption of low dose phytosterol and phytosterol esters made the phytosterol concentration in rat blood very low, which was lower than the detection limit of the HPLC. This finding was similar with to the results by Delaney (Delaney et al., 2004).

The highest value of PS concentration in blood was $21.82 \pm 1.36 \mu \mathrm{g} / \mathrm{mL}$ at $3 \mathrm{~h}$, and the lowest value was only $6.29 \pm 0.61 \mu \mathrm{g} / \mathrm{mL}$ (Table 3). $0.3-1.7 \mathrm{mg} / \mathrm{dL}$ of phytosterols are found in human serum under normal conditions, and PS levels in plasma have been showed to increase up to two-fold by dietary supplementation of 160-360 mg/day PS (Bradford \& Awad, 2007). Their report is in agreement with our results. The concentrations in blood were very safe level in this paper. At present, it is not very clear about the concentrations in blood and tissues at which PS become toxic in the rat or other animals.

\section{Distribution of phytosterol and phytosterol esters in rat tissues}

Phytosterol and phytosterol esters are digested and absorbed by the rats and will enter into tissues of the rat body, where they are likely to be enriched in some organs (Sanders et al., 2000).

Phytosterol esters were not detected in all of the rat tissues of the high, middle and low dose groups. Phytosterol could be detected, and the content of phytosterol in organs was higher than that in blood (Table 4, the data was PS concentration). This finding indicated that phytosterol ester was hydrolyzed into phytosterol and fatty acid in the rat's body. Phytosterol enters into organs through blood circulation to play its biological role (Nestel et al., 2001; Moghadasian et al., 2016). The high and middle doses of phytosterols mainly accumulate in the liver,

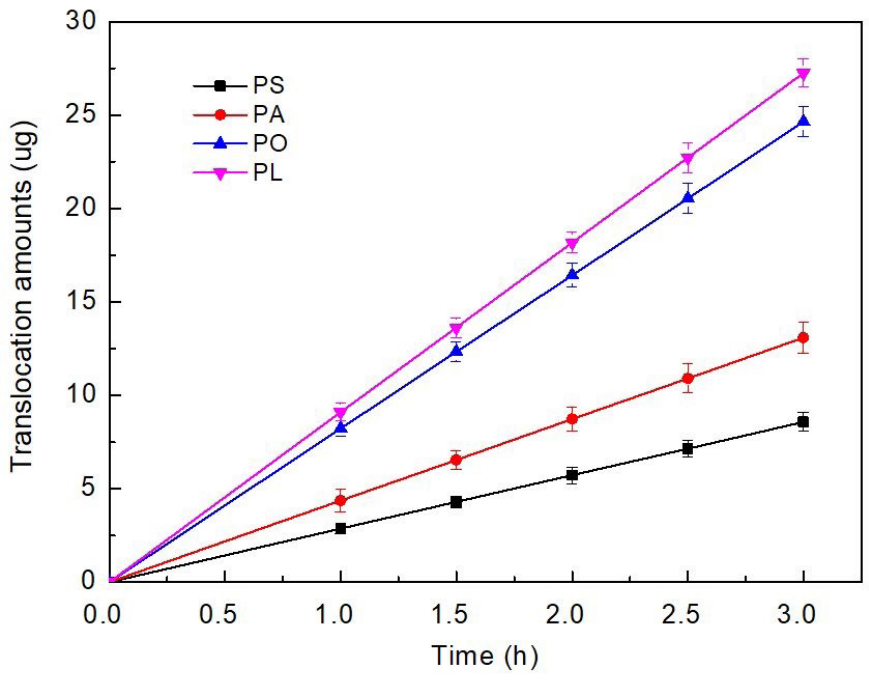

(A) AP side $\rightarrow$ BL side

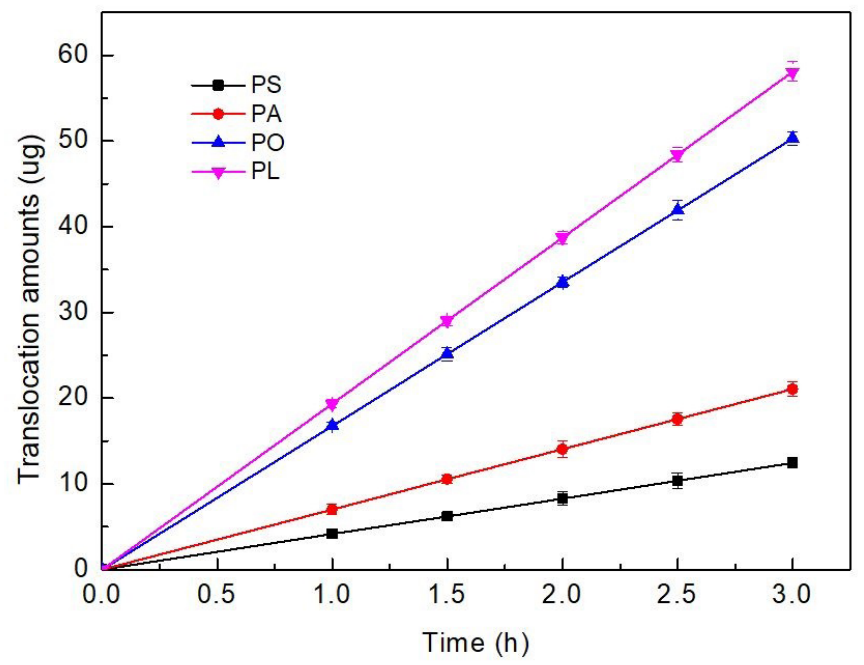

(B) BL side $\rightarrow$ AP side

Figure 5. Transport of phytosterol and phytosterol esters in Caco-2 cell monolayer with time.

Table 3. Phytosterol concentration in blood at different time $(\mu \mathrm{g} / \mathrm{mL})$.

\begin{tabular}{|c|c|c|c|c|c|c|}
\hline & & $1 \mathrm{~h}$ & $2 \mathrm{~h}$ & $3 \mathrm{~h}$ & $4 \mathrm{~h}$ & $5 \mathrm{~h}$ \\
\hline \multirow[t]{2}{*}{ PS } & high dose & $3.68^{c} \pm 0.54$ & $5.49^{\mathrm{b}} \pm 0.71$ & $7.71^{a} \pm 0.64$ & $7.38^{\mathrm{a}} \pm 0.98$ & $6.97^{\mathrm{a}} \pm 0.74$ \\
\hline & middle dose & $3.19^{c} \pm 0.42$ & $4.62^{\mathrm{b}} \pm 0.33$ & $6.29^{\mathrm{a}} \pm 0.61$ & $5.78^{a} \pm 0.64$ & $5.27^{\mathrm{ab}} \pm 0.72$ \\
\hline \multirow[t]{2}{*}{ PA } & high dose & $3.91^{c} \pm 0.74$ & $6.19^{\mathrm{b}} \pm 0.58$ & $8.47^{\mathrm{a}} \pm 0.82$ & $7.91^{a} \pm 0.92$ & $7.51^{\mathrm{ab}} \pm 0.49$ \\
\hline & middle dose & $4.01^{c} \pm 0.57$ & $5.29^{\mathrm{b}} \pm 0.75$ & $7.12^{\mathrm{a}} \pm 0.82$ & $6.51^{\mathrm{ab}} \pm 0.56$ & $5.91^{\mathrm{ab}} \pm 0.62$ \\
\hline \multirow[t]{2}{*}{$\mathrm{PO}$} & high dose & $9.28^{\mathrm{d}} \pm 0.84$ & $13.39^{c} \pm 1.32$ & $18.91^{\mathrm{a}} \pm 1.04$ & $17.02^{\mathrm{b}} \pm 0.98$ & $15.34^{\mathrm{b}} \pm 0.47$ \\
\hline & middle dose & $7.29^{\mathrm{d}} \pm 0.81$ & $11.37^{\mathfrak{c}} \pm 0.95$ & $16.21^{\mathrm{a}} \pm 1.12$ & $14.53^{\mathrm{ab}} \pm 0.83$ & $13.86^{\mathrm{b}} \pm 0.98$ \\
\hline \multirow[t]{2}{*}{ PL } & high dose & $10.73^{\mathrm{d}} \pm 0.66$ & $14.87^{b c} \pm 1.29$ & $21.82^{\mathrm{a}} \pm 1.36$ & $18.03^{b} \pm 0.87$ & $16.26^{b} \pm 0.75$ \\
\hline & middle dose & $8.73^{\mathrm{d}} \pm 0.77$ & $13.89^{c} \pm 1.26$ & $19.48^{\mathrm{a}} \pm 1.17$ & $17.18^{\mathrm{b}} \pm 1.25$ & $15.67^{b c} \pm 1.27$ \\
\hline
\end{tabular}

Mean \pm SD. Mean with different superscript along the same row of high dose and middle dose are significantly different $(\mathrm{p}<0.05)$ 
heart, and spleen, whereas the contents in the lung and kidney are relatively low. The values of the organs for each group were significantly different $(\mathrm{p}<0.05)$. PS content in the liver was the highest, and the highest value was $43.65 \mu \mathrm{g} / \mathrm{g}$ from the high dose of PL. PS content in the kidney was the lowest, and the value was $6.84 \mu \mathrm{g} / \mathrm{g}$ from the middle dose of PS (Table 4). This localization may be attributed to the liver being the main organ of fat metabolism and that liver has the function of biotransformation. The higher content of phytosterols in the liver is conducive to further transformation and playing its biological role (Yang et al., 2016). Sterols were not detected in the low dose group. The dose was too low, and the concentration of tissues was too low to be detected with the current method. Sanders (Sanders et al., 2000) studied the distribution of phytosterol esters in rat organs by isotope tracing. The results showed that phytosterols were highly distributed in liver and lung tissues. We found the same with phytosterol content in the liver. The distribution of PO and PL in rat tissues was more than 2 times higher than that in PS and PA groups; however, the same rule presented both in vitro and in rat blood.

This rat experiment was an acute study, the main purpose was to find the absorption and bioavailability differencs between PS and PE. The cholesterol concentration in blood might not change obviously. If a chronic study was done, all the PS and $\mathrm{PE}$ rat groups might have the cholesterol lowering effect, the cholesterol concentration of PL and PO groups might change more obviously.

\section{Phytosterol content in excreta of rats}

Phytosterol and phytosterol esters are digested and absorbed in the rat body, and some of them enter into the blood circulation and rat tissues. In addition, some of the unused phytosterol and phytosterol esters may be excreted through the feces but not urine (Table 5).

The feces contains large amounts of PS and PA, and there was almost no PO or PL. This result shows that the PO and PL were digested and absorbed in the animal, and they were completely converted into phytosterol and fatty acids. However, PA is an exception, as only a small part of the PA was converted into phytosterols by the animals, and the other PA was discharged. This difference may be attributed to the limited structural changes of PS after ethyl esterification; the structures of PA and PS are very similar, and the digestion and absorption of PA is also similar to PS, thus causing a large amount of PA and PS excretion. More than $95 \%$ of PS and PA were excreted in feces, and the bioavailability of phytosterols in rats was less than $5 \%$, which was related to the solubility of phytosterols in vivo (Yang et al., 2016, 2018b). The excretion proportions of PO and $\mathrm{PL}$ in rat feces of the middle and low dose groups ranged from 80.43 to $85.27 \%$, and the bioavailability rates of PO and PL

Table 4. Concentration of phytosterol in rat tissues $(\mu \mathrm{g} / \mathrm{g})$.

\begin{tabular}{ccccccc}
\hline & & heart & liver & spleen & lung & kidney \\
\hline PS & high dose & $14.17^{\mathrm{b}} \pm 0.49$ & $16.35^{\mathrm{a}} \pm 0.64$ & $11.13^{\mathrm{c}} \pm 0.53$ & $9.02^{\mathrm{d}} \pm 0.38$ & $8.31^{\mathrm{d}} \pm 0.42$ \\
& middle dose & $12.03^{\mathrm{b}} \pm 0.44$ & $13.25^{\mathrm{a}} \pm 0.48$ & $9.84^{\mathrm{c}} \pm 0.29$ & $7.93^{\mathrm{d}} \pm 0.47$ & $6.84^{\mathrm{e}} \pm 0.31$ \\
PA & high dose & $14.74^{\mathrm{b}} \pm 0.51$ & $17.02^{\mathrm{a}} \pm 0.73$ & $11.65^{\mathrm{c}} \pm 0.56$ & $9.23^{\mathrm{d}} \pm 0.42$ & $8.49^{\mathrm{d}} \pm 0.37$ \\
& middle dose & $12.61^{\mathrm{b}} \pm 0.53$ & $13.76^{\mathrm{a}} \pm 0.43$ & $10.25^{\mathrm{c}} \pm 0.48$ & $8.17^{\mathrm{d}} \pm 0.35$ & $7.18^{\mathrm{e}} \pm 0.39$ \\
PO & high dose & $34.21^{\mathrm{b}} \pm 1.71$ & $38.72^{\mathrm{a}} \pm 1.33$ & $26.74^{\mathrm{c}} \pm 0.83$ & $20.12^{\mathrm{d}} \pm 0.38$ & $19.22^{\mathrm{d}} \pm 0.78$ \\
& middle dose & $30.47^{\mathrm{a}} \pm 1.82$ & $32.11^{\mathrm{a}} \pm 1.51$ & $24.28^{\mathrm{b}} \pm 0.97$ & $18.33^{\mathrm{c}} \pm 0.42$ & $17.19^{\mathrm{c}} \pm 0.54$ \\
PL & high dose & $37.67^{\mathrm{b}} \pm 1.35$ & $43.65^{\mathrm{a}} \pm 1.42$ & $30.06^{\mathrm{c}} \pm 0.91$ & $25.02^{\mathrm{d}} \pm 0.69$ & $23.45^{\mathrm{d}} \pm 0.85$ \\
& middle dose & $35.42^{\mathrm{a}} \pm 1.71$ & $36.53^{\mathrm{a}} \pm 1.27$ & $27.43^{\mathrm{b}} \pm 0.79$ & $21.79^{\mathrm{c}} \pm 0.83$ & $20.39^{\mathrm{c}} \pm 0.78$ \\
\hline
\end{tabular}

Mean \pm SD. Mean with different superscript along the same row of high dose and middle dose are significantly different $(\mathrm{p}<0.05)$.

Table 5. Concentration (mg/g) and excretion proportion (\%) of phytosterol and phytosterol esters in faeces.

\begin{tabular}{|c|c|c|c|c|c|c|}
\hline & & PS content & $\begin{array}{l}\text { PS excretion } \\
\text { proportion }\end{array}$ & PE content & $\begin{array}{l}\text { PE excretion } \\
\text { proportion }\end{array}$ & $\begin{array}{c}\text { total excretion } \\
\text { proportion }\end{array}$ \\
\hline \multirow[t]{3}{*}{ PS } & high dose & $49.28^{a} \pm 2.19$ & $98.56^{\mathrm{a}} \pm 1.10$ & --- & --- & $98.56^{a} \pm 1.10$ \\
\hline & middle dose & $24.32^{\mathrm{a}} \pm 1.78$ & $97.28^{\mathrm{a}} \pm 1.78$ & ---- & ---- & $97.28^{\mathrm{a}} \pm 1.78$ \\
\hline & low dose & $2.40^{\mathrm{a}} \pm 0.27$ & $95.91^{\mathrm{a}} \pm 2.72$ & ---- & --- & $95.91^{\mathrm{a}} \pm 2.72$ \\
\hline \multirow[t]{2}{*}{ PA } & high dose & $35.46^{\mathrm{b}} \pm 2.73$ & $70.91^{c} \pm 1.37$ & $13.52^{\mathrm{a}} \pm 1.14$ & $27.03^{a} \pm 0.61$ & $97.94^{\mathrm{a}} \pm 1.98$ \\
\hline & middle dose & $17.43^{c} \pm 1.73$ & $69.71^{c} \pm 0.43$ & $6.61 \pm 0.84$ & $26.42 \pm 0.21$ & $96.13^{a} \pm 0.64$ \\
\hline \multirow[t]{3}{*}{$\mathrm{PO}$} & high dose & $45.81^{\mathrm{a}} \pm 2.17$ & $92.20^{\mathrm{b}} \pm 1.29$ & $0.29^{b} \pm 0.11$ & $0.58^{\mathrm{b}} \pm 0.21$ & $92.78^{\mathrm{b}} \pm 1.50$ \\
\hline & middle dose & $21.32^{\mathrm{b}} \pm 1.17$ & $85.27^{\mathrm{b}} \pm 1.17$ & ---- & ---- & $85.27^{b} \pm 1.17$ \\
\hline & low dose & $2.08^{\mathrm{a}} \pm 0.27$ & $83.12^{\mathrm{b}} \pm 2.74$ & ---- & ---- & $83.12^{\mathrm{b}} \pm 2.74$ \\
\hline \multirow[t]{2}{*}{ PL } & high dose & $45.46^{\mathrm{a}} \pm 2.35$ & $91.41^{\mathrm{b}} \pm 1.37$ & $0.24^{\mathrm{b}} \pm 0.09$ & $0.49^{b} \pm 0.19$ & $91.90^{\mathrm{b}} \pm 1.56$ \\
\hline & middle dose & $20.89^{b} \pm 1.35$ & $83.54^{\mathrm{b}} \pm 1.35$ & ---- & ---- & $83.54^{\mathrm{b}} \pm 1.35$ \\
\hline
\end{tabular}

Mean \pm SD. Mean with different superscript along the same column of high dose, middle dose and low dose are significantly different $(\mathrm{p}<0.05)$. 
in rats ranged from 14.73 to $19.57 \%$, which were significantly higher than those of PS and PA (Table 5). After esterification of phytosterols (especially PO and PL), the bioavailability of phytosterols in animals was greatly improved.

Different from the results of blood and tissue distribution, phytosterols and phytosterol esters were detected in rat feces of the low dose group, and the bioavailability of phytosterols and phytosterol esters in the low dose group was higher than those in the middle and high dose groups (Table 5). The dosage of the low dose group was designed according to the daily consumption of phytosterols and phytosterol esters recommended by the Health Ministry of China. The results showed that the bioavailabilities of rats in the PS and PA groups were less than $5 \%$. The bioavailabilities of rats in the PO and PL groups were 16.88 and $19.57 \%$, respectively (Table 5). According to the analysis of bioavailability of phytosterols and phytosterol esters in vivo, under the same absorption conditions, the bioavailabilities of PO and PL are high, and their therapeutic and preventive effects on diseases will be better than those of phytosterols. Clinical experiments have shown that daily intake of $8.6 \mathrm{~g}$ of phytosterol esters can significantly reduce the levels of total cholesterol and low density lipoprotein cholesterol in human plasma (Ayesh et al., 1999). According to this dose, $35.5 \mathrm{~g}$ of phytosterols per day is needed to achieve the same effect as $8.6 \mathrm{~g}$ of PO and PL. Such a large dose of phytosterols has no practical significance, and PO and PL have more advantages in application. Previous researchers dissolved radioactive labeled phytosterols in sunflower oil to determine the steroid content in the feces and urine of mice within $96 \mathrm{~h}$. They found that fecal phytosterol content is the highest, reaching 75.07-96.65\% (Sanders et al., 2000). This result is consistent with the conclusions drawn in this paper.

\section{Conclusions}

Three phytosterol esters were synthesized from phytosterols. Through a Caco-2 monolayer cell model and animal experiments, it was suggested that the bioavailability of PL and PO was higher than PS.

The Caco- 2 cell experiment showed that the bioavailability of PL was more than 3 times higher than that of PS.

The rat experiments showed that phytosterol and phytosterol esters were absorbed in 3 hours and that absorption of PL was highest at $3 \mathrm{~h}$. The content of phytosterols in the liver was higher than that in other organs, which indicated that the liver was the main tissue to absorb phytosterol and that the content of PL in rat feces was the lowest. In conclusion, the bioavailability of phytosterol in vivo and in vitro was better after esterification, especially for PL, whose bioavailability was 4 times higher than that of free PS.

\section{Acknowledgements}

This work was also supported by a grant from rice bran high-value steady-state processing technology and intelligent equipment research and demonstration (2018YFD0401101). The authors would like to thank the anonymous reviewers and the editor for their comments on this paper.

\section{References}

Artursson, P., Palm, K., \& Luthman, K. (2012). Caco-2 monolayers in experimental and theoretical predictions of drug transport. Advanced Drug Delivery Reviews, 64(1-2), 280-289. http://dx.doi. org/10.1016/j.addr.2012.09.005.

Ayesh, R., Weststrate, J. A., Drewitt, P. N., \& Hepburn, P. A. (1999). Safety evaluation of phytosterol esters. part 5. faecal short-chain fatty acid and microflora content, faecal bacterial enzyme activity and serum female sex hormones in healthy normolipidaemic volunteers consuming a controlled diet either with or without a phytosterol ester-enriched margarine. Food and Chemical Toxicology, 37(12), 1127-1138. http://dx.doi.org/10.1016/S0278-6915(99)00109-X. PMid:10654588.

Bacchetti, T., Masciangelo, S., Bicchiega, V., Bertoli, E., \& Ferretti, G. (2011). Phytosterols, phytostanols and their esters: from natural to functional foods. Mediterranean Journal of Nutrition and Metabolism, 4(3), 165-172. http://dx.doi.org/10.3233/s12349-010-0049-0.

Baker, V. A., Hepburn, P. A., Kennedy, S. J., Jones, P. A., Lea, L. J., Sumpter, J. P., \& Ashby, J. (1999). Safety evaluation of phytosterol esters. part 1. assessment of oestrogenicity using a combination of in vivo and in vitro assays. Food and Chemical Toxicology, 37(1), 13-22. http://dx.doi.org/10.1016/S0278-6915(98)00101-X. PMid:10069478.

Belo, R. G., Velasco, L., Nolasco, S. M., \& Izquierdo, N. G. (2018). Dynamics of phytosterols content and concentration in sunflower grains. Crop \& Pasture Science, 69(7), 724-732. http://dx.doi. org/10.1071/CP17438.

Bradford, P. G., \& Awad, A. B. (2007). Phytosterols as anticancer compounds. Molecular Nutrition \& Food Research, 51(2), 161-170. http://dx.doi.org/10.1002/mnfr.200600164. PMid:17266177.

Daujat, M., Charrasse, S., Fabre, I., Lesca, P., Jounaidi, Y., Larroque, C., Poellinger, L., \& Maurel, P. (1996). Induction of cypla1 gene by benzimidazole derivatives during caco- 2 cell differentiation. evidence for an aryl-hydrocarbon receptor-mediated mechanism. European Journal of Biochemistry, 237(3), 642-652. http://dx.doi. org/10.1111/j.1432-1033.1996.0642p.x. PMid:8647108.

Delaney, B., Stevens, L. A., Schmelzer, W., Haworth, J., McCurry, S., Hilfinger, J. M., Kim, J. S., Tsume, Y., Amidon, G. L., \& Kritchevsky, D. (2004). Oral absorption of phytosterols and emulsified phytosterols by sprague-dawley rats. The Journal of Nutritional Biochemistry, 15(5), 289-295. http://dx.doi.org/10.1016/j.jnutbio.2003.08.013. PMid:15135153.

During, A., \& Harrison, E. H. (2007). Mechanisms of provitamin a (carotenoid) and vitamin a (retinol) transport into and out of intestinal caco-2 cells. Journal of Lipid Research, 48(10), 2283-2294. http://dx.doi.org/10.1194/jlr.M700263-JLR200. PMid:17644776.

Elendran, S., Muniyandy, S., Lee, W. W., \& Palanisamy, U. D. (2019). Permeability of the ellagitannin geraniin and its metabolites in a human colon adenocarcinoma Caco- 2 cell culture model. Food \& Function, 10(2), 602-615. PMid:30566155.

Fakih, O., Sanver, D., Kane, D., \& Thorne, J. L. (2018). Exploring the biophysical properties of phytosterols in the plasma membrane for novel cancer prevention strategies. Biochimie, 153(10), 150-161. http://dx.doi.org/10.1016/j.biochi.2018.04.028. PMid:29730298.

Fernández-García, E., Carvajal-Lérida, I., \& Pérez-Gálvez, A. (2009). In Vitro Bioaccessibility Assessment as a Prediction Tool of Nutritional Efficiency. Nutrition Research, 29(11), 751-760. http://dx.doi. org/10.1016/j.nutres.2009.09.016. PMid:19932863.

Ghietto, L. M., Toigo D’Angelo, A. P., Viale, F. A., \& Adamo, M. P. (2017). Human bocavirus 1 infection of Caco-2 cell line cultures. 
Virology, 510, 273-280. http://dx.doi.org/10.1016/j.virol.2017.07.034. PMid:28777951.

Gol, D., Thakkar, S., \& Misra, M. (2018). Nanocrystal-based drug delivery system of risperidone: lyophilization and characterization. Drug Development and Industrial Pharmacy, 44(9), 1458-1466 . http://dx.doi.org/10.1080/03639045.2018.1 460377. PMid:29619857.

Gylling, H., Plat, J., Turley, S., Ginsberg, H. N., Ellegård, L., Jessup, W., Jones, P. J., Lütjohann, D., Maerz, W., Masana, L., Silbernagel, G., Staels, B., Borén, J., Catapano, A. L., De Backer, G., Deanfield, J., Descamps, O. S., Kovanen, P. T., Riccardi, G., Tokgözoglu, L., \& Chapman, M. J. (2014). Plant sterols and plant stanols in the management of dyslipidaemia and prevention of cardiovascular disease. Atherosclerosis, 232(2), 346-360. http://dx.doi.org/10.1016/j. atherosclerosis.2013.11.043. PMid:24468148.

Hang, J., \& Dussault, P. (2010). A concise synthesis of $\beta$-sitosterol and other phytosterols. Steroids, 75(12), 879-883. http://dx.doi. org/10.1016/j.steroids.2010.05.016. PMid:20685279.

He, B., Deng, T., Li, J., Yan, F., Wang, H., Huang, Y., \& Peng, C. (2014). An innovative auto-catalytic esterification for the production of phytosterol esters: experiment and kinetics. RSC Advances, 4(109), 64319-64327. http://dx.doi.org/10.1039/C4RA11702F.

Hellner, G., Tőke, E. R., Nagy, V., Szakács, G., \& Poppe, L. (2010). Integrated enzymatic production of specific structured lipid and phytosterol ester compositions. Process Biochemistry, 45(8), 12451250. http://dx.doi.org/10.1016/j.procbio.2010.04.008.

Hepburn, P. A., Horner, S. A., \& Smith, M. (1999). Safety evaluation of phytosterol esters. Part 2: subchronic 90-day oral toxicity study on phytosterol esters-a novel functional food. Food and Chemical Toxicology, 37(5), 521-532. http://dx.doi.org/10.1016/S02786915(99)00030-7. PMid:10456681.

Huang, J., Xu, M., Fang, Y. J., Lu, M. S., Pan, Z. Z., Huang, W. Q., Chen, Y. M., \& Zhang, C. X. (2017). Association between phytosterol intake and colorectal cancer risk: a case-control study. British Journal of Nutrition, 117(6), 839-850. http://dx.doi.org/10.1017/ S0007114517000617. PMid:28382872.

Iftikhar, M., Iftikhar, A., Zhang, H., Gong, L., \& Wang, J. (2020). Transport, metabolism and remedial potential of functional food extracts (ffes) in Caco-2 cells monolayer: a review. Food Research International, 136, 109240. http://dx.doi.org/10.1016/j.foodres.2020.109240. PMid:32846508.

Ito, N., Ohtsubo, T., Kusu, F., \& Hakamata, H. (2012). An ultra performance liquid chromatographic method for determining phytosterol uptake by Caco-2 cells. Analytical Biochemistry, 421(1), 86-91. PMid:22119071.

Keemink, J., \& Bergström, C. A. S. (2018). Caco-2 cell conditions enabling studies of drug absorption from digestible lipid-based formulations. Pharmaceutical Research, 35(4), 74-78. http://dx.doi. org/10.1007/s11095-017-2327-8. PMid:29484506.

Kritchevsky, D., \& Chen, S. C. (2005). Phytosterols-health benefits and potential concerns: a review. Nutrition Research (New York, N.Y.), 25(5), 413-428. http://dx.doi.org/10.1016/j.nutres.2005.02.003.

Lea, L. J., Hepburn, P. A., Wolfreys, A. M., \& Baldrick, P. (2004). Safety evaluation of phytosterol esters. Part 8. Lack of genotoxicity and subchronic toxicity with phytosterol oxides. Food and Chemical Toxicology, 42(5), 771-783. http://dx.doi.org/10.1016/j.fct.2003.12.014. PMid:15046823.

Li, Y. J., Hu, X. B., Lu, X. L., Liao, D. H., Tang, T. T., Wu, J. Y., \& Xiang, D. X. (2017). Nanoemulsion-based delivery system for enhanced oral bioavailability and caco- 2 cell monolayers permeability of berberine hydrochloride. Drug Delivery, 24(1), 1868-1873. http://dx.doi.org/ 10.1080/10717544.2017.1410257. PMid:29191058.

Ling, W. H., \& Jones, P. J. H. (1995). Dietary phytosterols: a review of metabolism, benefits and side effects. Life Sciences, 57(3), 195-206. http://dx.doi.org/10.1016/0024-3205(95)00263-6. PMid:7596226.

Manna, C., Galletti, P., Maisto, G., Cucciolla, V., D’Angelo, S., \& Zappia, V. (2000). Transport mechanism and metabolism of olive oil hydroxytyrosol in caco-2 cells. FEBS Letters, 470(3), 341-344. http:// dx.doi.org/10.1016/S0014-5793(00)01350-8. PMid:10745093.

Marangoni, F., \& Poli, A. (2010). Phytosterols and cardiovascular health. Pharmacological Research, 61(3), 193-199. http://dx.doi. org/10.1016/j.phrs.2010.01.001. PMid:20067836.

Meng, X., Pan, Q., \& Yang, T. (2011). Synthesis of phytosteryl esters by using alumina-supported zinc oxide $(\mathrm{ZnO} / \mathrm{Al} 2 \mathrm{O} 3)$ from esterifification production of Phytosterol with fatty acid. Journal of the American Oil Chemists' Society, 88(1), 143-149. http://dx.doi.org/10.1007/ s11746-010-1654-2.

Moghadasian, M. H., Tan, Z., Le, K., \& Shahidi, F. (2016). Antiatherogenic effects of phytosteryl oleates in apo-e deficient mice. Journal of Functional Foods, 21, 97-103. http://dx.doi.org/10.1016/j. jff.2015.11.031.

Moreau, R. A., Nyström, L., Whitaker, B. D., Winkler-Moser, J. K., Baer, D. J., Gebauer, S. K., \& Hicks, K. B. (2018). Phytosterols and their derivatives: Structural diversity, distribution, metabolism, analysis, and health-promoting uses. Progress in Lipid Research, 70, 35-61. http://dx.doi.org/10.1016/j.plipres.2018.04.001. PMid:29627611.

Mu, H., \& Porsgaard, T. (2005). The metabolism of structured triacylglycerols. Progress in Lipid Research, 44(6), 430-448. http:// dx.doi.org/10.1016/j.plipres.2005.09.002. PMid:16269186.

Nestel, P., Cehun, M., Pomeroy, S., Abbey, M., \& Weldon, G. (2001). Cholesterol-lowering effects of plant sterol esters and non-esterified stanols in margarine, butter and low-fat foods. European Journal of Clinical Nutrition, 55(12), 1084-1090. http://dx.doi.org/10.1038/ sj.ejcn.1601264. PMid:11781675.

Nguyen, H. C., Huang, K. C., \& Su, C. H. (2019). Green process for the preparation of phytosterol esters: microwave-mediated noncatalytic synthesis. Chemical Engineering Journal, 382, 1-7.

Prasanna Rani, K. N., Ramana Neeharika, T. S. V., Kumar, T. P., Satyavathi, B., \& Sailu, C. (2016). Kinetics of non-catalytic esterification of free fatty acids present in jatropha oil. Journal of Oleo Science, 65(5), 441-445. http://dx.doi.org/10.5650/jos.ess15255. PMid:27086997.

Ren, M., Song, S., Liang, D., Hou, W., Tan, X., \& Luo, J. (2016). Comparative tissue distribution and excretion study of alkaloids from Herba Ephedrae-Radix Aconiti Lateralis extracts in rats. Journal of Pharmaceutical and Biomedical Analysis, 134, 137-144. http:// dx.doi.org/10.1016/j.jpba.2016.11.027. PMid:27912193.

Rocha, M., Banuls, C., Bellod, L., Jover, A. M., Victor, V., \& HernandezMijares, A. (2011). A review on the role of phytosterols: new insights into cardiovascular risk. Current Pharmaceutical Design, 17(36), 4061-4075. http://dx.doi.org/10.2174/138161211798764852. PMid:22188455.

Sanders, D. J., Minter, H. J., Howes, D., \& Hepburn, P. A. (2000). The safety evaluation of phytosterol esters. part 6 . the comparative absorption and tissue distribution of phytosterols in the rat. Food and Chemical Toxicology, 38(6), 485-491. http://dx.doi.org/10.1016/ S0278-6915(00)00021-1. PMid:10828500.

Trujillo, A. J., Corredig, M., Fernandez-Avila, C., Arranz, E., \& Guri, A. (2016). Vegetable Protein Isolate Stabilized Emulsions for 
Enhanced Delivery of Conjugated Linoleic Acid in Caco-2 Cells. Food Hydrocolloids, 55, 144-154. http://dx.doi.org/10.1016/j. foodhyd.2015.10.015.

Turowski, G. A., Rashid, Z., Hong, F., Madri, J. A., \& Basson, M. D. (1994). Glutamine modulates phenotype and stimulates proliferation in human colon cancer cell lines. Cancer Research, 54(22), 59745980. PMid:7954430.

Valange, S., Beauchaud, A., Barrault, J., Gabelica, Z., Daturi, M., \& Can, F. (2008). Lanthanum oxides for the selective synthesis of phytosterol esters: correlation between catalytic and acid-base properties. Journal of Catalysis, 251(1), 113-122. http://dx.doi.org/10.1016/j. jcat.2007.07.004.

Vila, L., García-Rodríguez, A., Cortés, C., Velázquez, A., Xamena, N., Sampayo-Reyes, A., Marcos, R., \& Hernández, A. (2018). Effects of cerium oxide nanoparticles on differentiated/undifferentiated human intestinal Caco-2 cells. Chemico-Biological Interactions, 283, 38-46. http://dx.doi.org/10.1016/j.cbi.2018.01.018. PMid:29378162.

Villeneuve, P., Turon, F., Caro, Y., Escoffier, R., Baréa, B., Barouh, B., Lago, R., Piombo, G., \& Pina, M. (2005). Lipase-catalyzed synthesis of canola phytosterols oleate esters as cholesterol lowering agents. Enzyme and Microbial Technology, 37(1), 150-155. http://dx.doi. org/10.1016/j.enzmictec.2005.02.002.

Wahlang, B., Pawar, Y. B., \& Bansal, A. K. (2011). Identification of permeability-related hurdles in oral delivery of curcumin using the caco-2 cell model. European Journal of Pharmaceutics and Biopharmaceutics, 77(2), 275-282. http://dx.doi.org/10.1016/j. ejpb.2010.12.006. PMid:21147222.

Wolfreys, A. M., \& Hepburn, P. A. (2002). Safety evaluation of phytosterol esters. Part 7: assessment of mutagenic activity of phytosterols, phytosterol esters and the cholesterol derivative, 4-cholesten-3one. Food and Chemical Toxicology, 40(4), 461-470. http://dx.doi. org/10.1016/S0278-6915(01)00099-0. PMid:11893405.

Xiang, Q. F., Zhang, W. J., Li, Q., Zhao, J., Feng, W., Zhao, T., Mao, G., Chen, Y., Wu, X., Yang, L., \& Chen, G. (2020). Investigation of the uptake and transport of polysaccharide from Se-enriched Grifola frondosa in Caco-2 cells model. International Journal of Biological Macromolecules, 158, 1330-1341. http://dx.doi.org/10.1016/j. ijbiomac.2020.04.160. PMid:32339585.

Yang, F., Oyeyinka, S. A., \& Ma, Y. (2016). Novel synthesis of phytosterol ester from soybean sterol and acetic anhydride. Journal of Food Science, 81(7), C1629-C1635. http://dx.doi.org/10.1111/17503841.13354. PMid:27240315.

Yang, F., Chen, G., Ma, M., Qiu, N., Zhu, L., \& Li, J. (2018a). Fatty acids modulate the expression levels of key proteins for cholesterol absorption in Caco-2 monolayer. Lipids in Health and Disease, 17(1), 32-39. http://dx.doi.org/10.1186/s12944-018-0675-y. PMid:29463265.

Yang, F., Oyeyinka, S. A., Xu, W. L., Ma, Y., \& Zhou, S. B. (2018b). In vitro bioaccessibility and physicochemical properties of phytosterol linoleic ester synthesized from soybean sterol and linoleic acid. Lebensmittel-Wissenschaft + Technologie, 92, 265-271. http://dx.doi. org/10.1016/j.lwt.2018.02.031.

Yang, X. W., Guo, Q. M., Wang, Y., Xu, W., Tian, L., \& Tian, X. J. (2007). Intestinal permeability of antivirus constituents from the fruits of eucalyptus globulus labill. in caco-2 cell model. Bioorganic \& Medicinal Chemistry Letters, 17(4), 1107-1111. http://dx.doi.org/10.1016/j. bmcl.2006.11.021. PMid:17118653.

Ye, Z., Li, R. Z., Cao, C., Xu, Y. J., Cao, P. R., Li, Q., \& Liu, Y. F. (2019). Fatty acid profifiles of typical dietary lipids after gastrointestinal digestion and absorbtion: a combination study between in-vitro and in-vivo. Food Chemistry, 280, 34-44. http://dx.doi.org/10.1016/j. foodchem.2018.12.032. PMid:30642504.

Yee, S. (1997). In vitro permeability across caco-2 cells (colonic) can predict in vivo (small intestinal) absorption in man-fact or myth. Pharmaceutical Research, 14(6), 763-766. http://dx.doi. org/10.1023/A:1012102522787. PMid:9210194.

Zeng, Z., Shen, Z. L., Zhai, S., Xu, J. L., Liang, H., Shen, Q., \& Li, Q. Y. (2017). Transport of curcumin derivatives in caco-2 cell monolayers. European Journal of Pharmaceutics and Biopharmaceutics, 117, 123 131. http://dx.doi.org/10.1016/j.ejpb.2017.04.004. PMid:28396278. 